\title{
Assessment of water quality status of Anjarakandy river in Kannur district of Kerala
}

\section{N. ATHIRA AND D.S. JAYA}

Article Chronicle :

Received :

17.10.2014;

Revised :

01.11.2014;

Accepted :

15.11.2014
SUMMARY : The rivers always form the lifeline of nation and society by providing precious resources for development and perpetuation of life. In India, the surface water, especially rivers form an inevitable part of culture and are used as drinking and irrigational water source. The present study focus on the assessment of seasonal changes in water quality of the Anjarakandy River in Kannur District, Kerala during the pre monsoon and monsoon seasons of the year 2013. The physical, chemical and bacteriological attributes of the river water were analyzed, and based on the selected parameters, the Water Quality Index (WQI) was calculated. The results show that there is chemical pollution of river water due to chloride, salinity, total hardness, sulphates, sodium, potassium etc. especially in down stretches of the river, where the severity of saltwater intrusion is common. The upstream portions of the river show high MPN values for total and fecal coliform bacteria, which indicate the organic pollution by excreta of warm blooded animals. From the water quality index values determined, it was found that the river water is 'Unfit For Drinking'. Based on the values of Sodium Adsorption Ratio and Percentage Sodium determined, it was found that the water of Anjarakandy River is suitable for irrigation.

HOW TO CITE THIS ARTICLE : Athira, N. and Jaya, D.S. (2014). Assessment of water quality status of Anjarakandy river in Kannur district of Kerala. Asian J. Environ. Sci., 9(2): 68-74.

Key Words :

Anjarakandy river, Water quality index, Irrigational quality, Sodium adsorption ratio, Percentage sodium, Coliforms 